\title{
Electro-Fenton for Industrial Wastewater Treatment: A Review
}

\author{
Elin Marlina ${ }^{1, *}$ and Purwanto ${ }^{2}$ \\ ${ }^{1}$ Master Program of Environmental Science, School of Postgraduate Studies, Diponegoro University, Semarang - Indonesia \\ ${ }^{2}$ Department of Chemical Engineering, Faculty of Engineering, Diponegoro University, Semarang - Indonesia
}

\begin{abstract}
Electro-Fenton is part of electrochemical advanced oxidation processes (EAOPs) which have been widely used to treat various types of waste such as color, drugs, phenol compounds, leachate, surfactants, and others. This article focuses on the effects of various operating parameters and recent developments in the electro-Fenton process, and then their optimum ranges for maximum pollutant removal and various pollutants removed by this process is observed.
\end{abstract}

Keywords: Electro-Fenton; industrial wastewater treatment.

\section{Introduction}

The size of the industry influences the magnitude of environmental pollution. Various studies have been conducted with various types of methods to reduce and even eliminate various unwanted compounds in water such as by coagulation, adsorption, oxidation, biological processing, and electrochemical.

Electro-AOPs has various types of methods such as anodic oxidation, anodic oxidation by electroregeneration $\mathrm{H}_{2} \mathrm{O}_{2}$, electro-Fenton (EF), photo electroFenton and solar photo EF. All of the methods can be used with or without combination with another process such as biological processes, coagulation, electrocoagulation, and filters with membrane [1].

Of the various types of EAOPs that are being widely discussed are EAOPs that use Fenton reagents, this technology is used to eliminate persistent organic pollutants. There are two types of processing that are very well known, namely electro-Fenton and photoelectron-Fenton [2].

\section{E-Fenton}

The electro-Fenton processing technology is part of the most famous electrochemical advanced oxidation processes (EAOPs). The EAOPs process itself is the latest process of advance oxidation processes (AOPs) which has been developed a lot this decade. The EAOPs process is a new technology that has clean, efficient and economical processing in removing pollutants in water [3].

In general, the EF process has two different types, first type Fenton reagent has been added to the process from outside and the second configuration is $\mathrm{H}_{2} \mathrm{O}_{2}$ added from the external process while $\mathrm{Fe}^{2+}$ is provided from the process of anode reduction results [4].
EF process using the $\mathrm{OH}$ radical derived from the reaction of $\mathrm{H}_{2} \mathrm{O}_{2}$ and $\mathrm{Fe}^{2+}$ by chemical reactions such as the following equation [5]:

$$
\begin{aligned}
& \mathrm{Fe}^{3+}+\mathrm{H}_{2} \mathrm{O}_{2} \rightarrow \mathrm{Fe}^{2+}+\mathrm{H}++\mathrm{HO}_{2} \\
& \mathrm{Fe}^{3+}+\mathrm{HO} \cdot 2 \rightarrow \mathrm{Fe}^{2+}+\mathrm{H}++\mathrm{O}_{2} \\
& \mathrm{Fe}^{3+}+\mathrm{R} \bullet \rightarrow \mathrm{Fe}^{2+}+\mathrm{R}+ \\
& \mathrm{Fe}^{2+}+\mathrm{HO} \cdot 2 \rightarrow \mathrm{Fe}^{3+}+\mathrm{HO}^{2-}
\end{aligned}
$$

\section{Affecting factors}

\subsection{Electrode Type}

Determination of electrode types is one of the important steps in EF, electrode type's cause efficient or inefficiencies EF such as the unstable electrode will decrease process. Electrode with high oxygen overvoltage can increase $\mathrm{OH}$ radicals in the EF system as shown below [5]:

$$
\mathrm{H}_{2} \mathrm{O} \rightarrow \mathrm{HO} \cdot+\mathrm{H}^{+}+\mathrm{e}^{-}
$$

In a long time electrode, $\mathrm{Pt}$ has been used as an electrode material with a great conductivity and chemical constantly when potential is increased and highly corrosive media [6]. Platinum anodes have been used in greater amounts for the degradation of pollutants in the EF process than other types of anodes. But in the last decade boron-doped diamond (BDD) anode is widely used for EF processes [5]. The feasibility of Titanium (Ti) rods coated with $\mathrm{IrO}_{2} / \mathrm{RuO}_{2}$ in the electroFenton process has been studied [7]. $\mathrm{TiO}_{2} / \mathrm{Ti}$ was studied by [8]. $\mathrm{Ti} / \mathrm{RuO}_{2}-\mathrm{IrO}_{2}-\mathrm{SnO}_{2}-\mathrm{TiO}_{2}$ Ti nets [9]. Iron is a type of electrode that recently used this decade that was studied [10, 12], iron plate [13].

In addition to the types of electrodes mentioned above, there are types of modified electrodes that have removal capabilities like other conventional electrodes, as done by [14] that use melamine foam modified by

\footnotetext{
* Corresponding author: elin.marlina95@gmail.com
} 
$\mathrm{Fe}_{3} \mathrm{O}_{4}$ coated multi-walled carbon nanotube (MWCNT) polytetrafluoroethylene (PTFE) as a source of regeneration of $\mathrm{H}_{2} \mathrm{O}_{2}$ in the EF process.

\section{$3.2 \mathrm{pH}$}

EF process is strongly influenced by the $\mathrm{pH}$ value of the solution because in general the electro-Fenton process is carried out under acidic conditions, many studies have stated that the EF process is optimal at acidic $\mathrm{pH}$ ([8 $10],[15,16])$. In the previous Fenton process, iron will begin to settle as iron hydroxide at a higher $\mathrm{pH}$, but iron can form a stable bond with $\mathrm{H}_{2} \mathrm{O}_{2}$ at an acid $\mathrm{pH}$ value which causes inactivation of the catalyst [5].

The optimal leachate removal at $\mathrm{pH} 3$ by conducting experiments in the $\mathrm{pH}$ range 7-8 using graphite electrodes [17]. The same $\mathrm{pH}$ value, namely 3 in treating leachate waste using the Ti cathode [8]. In the processing of industrial dye waste with $\mathrm{Pt}$ anode and cathode activated carbon coated by polyacrylonitrile (PAN) obtained optimal conditions $\mathrm{pH}$ is 3 from the experimental process with a $\mathrm{pH}$ of 2,3,4,5 [18]. [16] also conducted an experiment to exclude antimicrobial sulfamethazine, carried out experiments on acidic $\mathrm{pH}$ conditions to neutral $(2-6)$ and obtained optimal $\mathrm{pH} 3$. Other studies confirmed that the electro-Fenton process is optimal in acidic conditions indicated [19] which removes phenol by comparing the Fenton process and electro-Fenton.

\subsection{Current density}

Current density is a trigger factor to reduce oxygen to produce regeneration of hydrogen peroxide at the cathode [5]. The use of high currents causes an increase in the production of quantum hydrogen peroxide which causes an increase in the amount of $\mathrm{OH}$ - so that the degradation process is increasingly reactive and responsive. In addition to increasing the amount of $\mathrm{OH}$ • in the solution, the use of high currents also causes an increase in regeneration of iron ions in which the efficiency of the Fenton process also increases. The use of high currents will result in increased voltage in the electrochemical process (Table 1).

Table 1. Optimum CD values of EF process in various studies.

\begin{tabular}{|c|c|c|c|}
\hline Pollutant & Condition & Flow & Efficiency \\
\hline $\begin{array}{l}\text { Methyl } \\
\text { orange } \\
{[20]}\end{array}$ & $\begin{array}{l}\text { Graphite electrode } \\
\text { modified activated } \\
\text { carbon and } \\
\text { polytetrafluoroethyl } \\
\text { ene }(\mathrm{PTFE}), \mathrm{MO}= \\
50 \mathrm{mg} / \mathrm{L}, \mathrm{pH}=3, \\
\text { time }=35 \text { minutes }\end{array}$ & $50 \mathrm{~A} / \mathrm{m}^{2}$ & Complete \\
\hline $\begin{array}{l}\text { Anionic } \\
\text { surfactant } \\
\text { (LAS) } \\
{[21]}\end{array}$ & $\begin{array}{l}\text { Anode } \mathrm{Ti} / \mathrm{RuO}_{2}, \\
\text { graphite cathode, } \\
\mathrm{LAS}=50 \mathrm{mg} / \mathrm{L}, \\
{\left[\mathrm{Fe}^{2+}\right]=0.3 \mathrm{mM},} \\
\mathrm{pH}=3, \text { time }=180 \\
\text { minutes }\end{array}$ & $200 \mathrm{~mA}$ & Complete \\
\hline
\end{tabular}

\begin{tabular}{|c|c|c|c|}
\hline $\begin{array}{l}\text { Ibuprofen } \\
\text { [22] }\end{array}$ & $\begin{array}{l}\text { Anode }=\mathrm{Pt}, \\
\text { cathode }=3 \mathrm{D} \\
\text { graphite, mother }= \\
0.2 \mathrm{mM},\left[\mathrm{Fe}^{3+}\right]= \\
0.2, \text { time }=50 \\
\text { minutes }\end{array}$ & $50 \mathrm{~mA}$ & Complete \\
\hline $\begin{array}{l}\text { Tartrazine } \\
\text { [7] }\end{array}$ & $\begin{array}{l}\text { Anode }=\mathrm{Ti} / \mathrm{IrO}_{2}- \\
\mathrm{RuO}_{2} \text {, continuous } \\
\text { system, cathode }= \\
\text { diffusion electrode } \\
\text { gas, } \mathrm{pH}=3\end{array}$ & $200 \mathrm{~mA}$ & $80 \%$ \\
\hline $\begin{array}{l}\text { E. coli } \\
{[23]}\end{array}$ & $\begin{array}{l}\text { Anode }=\mathrm{Pt}, \\
\text { cathode }=\text { stainless } \\
\text { steel, distance }=4 \\
\mathrm{~cm},\end{array}$ & $0.5 \mathrm{~A}$ & Inactive \\
\hline
\end{tabular}

\section{4 $\mathrm{Fe}^{2+}$}

The suitability of the number of iron ion concentrations in the EF process is an important requirement [23]. In general, the efficiency of EF process is affected by increasing the concentration of $\mathrm{Fe}^{2+}$ because as an agent of oxidizing in $\mathrm{EF} \mathrm{Fe}^{2+}$ had a big effect to reduce big molecule in wastewater such as dyes in dyeing wastewater [5]. The efficiency of antimicrobial sulfamethazine mineralization reached $94 \%$ by adding $0.5 \mathrm{mM} \mathrm{Fe}^{2+}$ for 420 minutes [16]. Removal of aspirin and increased organic total when the concentration of $\mathrm{Fe}^{2+}$ exceeded $0.1 \mathrm{mM}$ to reach $100 \%$ in 30 minutes [24].

\subsection{Hydrogen Peroxide}

The initial concentration of $\mathrm{H}_{2} \mathrm{O}_{2}$ plays an important role in electro-Fenton processes. The removal of pollutants increases with an increasing concentration of $\mathrm{H}_{2} \mathrm{O}_{2}$. Increased efficiency is caused by an increase in hydroxyl radical concentration as a result of the addition of $\mathrm{H}_{2} \mathrm{O}_{2}$ [25].

The concentration $\mathrm{H}_{2} \mathrm{O}_{2}$ optimum will produce economically efficient processing, wastewater from the fertilizer industry containing $435 \mathrm{mg} / \mathrm{L}$ organic total can be set aside to $84 \%$ by increasing the dose of $\mathrm{H}_{2} \mathrm{O}_{2}$ to 25 $\mathrm{mm}$ in just 10 minutes [25]. Gümüş [19] reported that as the number of $\mathrm{H}_{2} \mathrm{O}_{2}$ increases, the allowance for phenol has increased, this also applies to the allowance for COD. The concentration of $\mathrm{H}_{2} \mathrm{O}_{2}$ used in the cleaning process is very dependent on the type of waste to be treated, to clean up the phenol content of $\mathrm{H}_{2} \mathrm{O}_{2}$ as much as $37.2 \mathrm{mM}$ in a stoichiometric condition where phenol can be optimally set aside in just 5 minutes [12].

\section{$3.6 \mathrm{O}_{2}$ flow rate}

Regenerate $\mathrm{H}_{2} \mathrm{O}_{2}$ in $\mathrm{EF}$ is affected by oxygen concentration, therefor $\mathrm{O}_{2}$ flowrate is one of the main factors limiting the performance of the EF system because increasing the rate of oxygen filling can increase dissolved oxygen concentration and the rate of mass transfer of dissolved oxygen and ultimately increase hydrogen peroxide production [26]. The research 
conducted by [27] which varied the rate of addition of $\mathrm{O}_{2}$ from $0-0.28 \mathrm{~L} / \mathrm{min}$ reported that the most concentrations of $\mathrm{H}_{2} \mathrm{O}_{2}$ were produced at a concentration of $0.21 \mathrm{~L} /$ minute because when the rate $\mathrm{O}_{2}$ exceeds 0.28 $\mathrm{L} /$ minutes there is an excess of bubbles which decreases regeneration of $\mathrm{H}_{2} \mathrm{O}_{2}$ in the process. The addition of $\mathrm{O}_{2}$ from outside has also been done by [28] with an $\mathrm{O}_{2}$ flow rate of $1 \mathrm{~L} /$ minute for 10 minutes before the electrolysis process begins.

\subsection{Electrode gap}

Electrode distance in the EF process is one of the important factors for increasing the efficiency of pollutant removal, the COD removal increases with the closer the distance between electrodes, this is also proportional to energy consumption when the distance between electrodes farther away from the energy consumption increases [29]. The optimal distance for removing organic total in waste with a reactive blue 19 (RB19) content is $3 \mathrm{~cm}$ with an efficiency of $74.3 \%$ in optimal consumption [30]. Removal of phenol using iron electrodes gives different processing efficiencies in line with changing electrode distances from 2 to $6 \mathrm{~cm}$ when processing at the stoichiometric conditions the optimum processing distance is $4 \mathrm{~cm}$ with processing efficiency reaching $75 \%$ by adding activated carbon.

\subsection{Temperature}

The temperature has a great effect on increases efficiency of treatment at Fenton and related processes, it increases the removal of organic compounds because the temperature is relatively small compared to other factors [5]. Temperatures that are too low and too high have a negative impact on process efficiency, optimal temperature in the study conducted is $60^{\circ} \mathrm{C}$ where decoloration has increased with increasing temperature to reach an efficiency of $93.46 \%$, this is because the color allowance will increase when the processing temperature increases [18].

\subsection{Electrolyte}

Electrolytes help increase the conductivity of the solution and increase the acceleration of the electron transfer process which gives an advantage to the electroFenton process for the addition of electrolytes which are considered especially important for solutions with low conductivity content [5]. Sodium sulfate is a type of electrolyte that is widely used to increase the conductivity of solutions, as was done by [31] who added $0.05 \mathrm{M} \mathrm{Na}_{2} \mathrm{SO}_{4}$ to a waste solution containing dyes $[11,32,33]$. In addition to $\mathrm{Na}_{2} \mathrm{SO}_{4}$ there are other types of electrolytes which are often used, among others, $\mathrm{NaCl}, \mathrm{KCl}$, and $\mathrm{MgSO}_{4}$, which turns out that $\mathrm{NaCl}$ electrolyte is the most superior type of electrolyte in removing dyes compared to the other three electrolytes with $80 \%$ efficiency in time 15 minutes and optimal process conditions [10].

\section{Application}

\subsection{Color}

The use of coloring agents in various types of industries will not only cause changes in the color of water but can cause damage to other environments that are more serious such as obstruction of sunlight entering the water so that it can reduce water quality due to lack of oxygen in water the process of photosynthesis in water which causes the death of aquatic organisms.

Some types of dyes are classified as toxic and carcinogenic in nature. The presence of dye content in water is caused by industrial activities such as $60 \%$ caused by the textile industry, $10 \%$ in the paper and plastic industry $(10 \%)$ [34].

EF process is considered as one of the technologies that are considered capable of setting aside highly effective colors [5]. Cruz-González [35] reported that the removal of Acid Yellow 36 (Ay 36) by electro-Fenton reached $97.8 \%$ which was operated under optimum conditions. Alizarin Red with a concentration of $200 \mathrm{mg}$ / L was able to be completely eliminated by electroFenton [36] and the organic total was able to be set aside up to $95 \%$ after 210 minutes of processing by adding $\mathrm{Fe}^{2+}$ as much as $0.2 \mathrm{~mm}$. The removal of COD in dyecontaining textile industrial wastes was carried out, which reported that $75.2 \%$ COD was removed from waste by adding $\mathrm{O}_{2}$ to the electro-Fenton process as much as $150 \mathrm{~cm}^{3} /$ minute [15]. Malakootian [10] reported that $99.9 \% \pm 0.2 \%$ Acid Red 18 in synthetic waste and $90.5 \% \pm 1.7 \%$ in original waste were able to be removed using iron electrodes in the electro-Fenton process.

\subsection{Leachate}

Leachate that comes from landfill activities is very possible to pollute the environment. Leachate production is influenced by the presence of rainwater, precipitation and the degradation process of the waste itself so that leachate can form which can penetrate the soil and contaminate groundwater. There are contents of dangerous heavy metals such as lead (lead), zinc (ZINC), copper (copper), manganese (manganese), cadmium (cadmium), etc. in groundwater caused by contamination of leachate water [17].

Leachate has been treated by EF and carried out $72 \%$ COD, $90 \%$ color, $87 \% \mathrm{PO}_{4}-\mathrm{P}$ and $26 \% \mathrm{NH}_{4}-\mathrm{N}$ were able to be excluded under the optical conditions [4]. Adding a modified catalyst in the electro-Fenton process was able to set aside $87 \% \mathrm{COD}$ in leachate [17]. The results of EF leachate processing showed a decrease in COD from $7.184 \mathrm{mg} / \mathrm{L}$ to $1,293 \mathrm{mg} / \mathrm{L}$ with a BOD5/COD ratio of 0.03 to 0.40 which showed an increase in the biodegradable level of the leachate obtained from oxidation in organic leachate by $\mathrm{OH}$ radical [8].

The electro-Fenton process is not separated from the mud as a byproduct, the sediment characteristics resulting from EF processes were quite good [6]. 
Because with EF 73 types of pollutants found in leachate, 52 species can be eliminated [9].

\subsection{Drugs}

Along with the increasing number and types of drug industries, removal of pharmaceutical compounds in water and wastewater has been focused in over the past decade, these contaminants are sourced from the industrial process, direct disposal from households and livestock and other maintenance activities in industries [5]. To avoid the harmful health effects of pollutants a strong oxidation method is needed to remove drugs and their metabolites from wastewater, oxidation process has been researched in this decade is EF to removal ibuprofen [21], sulfamethazine [15], acetylsalicylic acid [22], chloramphenicol and metronidazole [36].

The hydro-organic content of ibuprofen was able to be completely removed by electro-Fenton using $\mathrm{Pt}$ anode with graphite cathode at $\mathrm{pH} 3$, adding $\mathrm{Fe}^{3+}$ catalyst 0.2 $\mathrm{mM}$ and the $\mathrm{Na}_{2} \mathrm{SO}_{4}$ electrolyte, $\mathrm{H}_{2} \mathrm{O}_{2}$ resulting from $\mathrm{O}_{2}$ solution derived from outer aeration at the rate of $1 \mathrm{~L} /$ minute for 10 minutes before the process [22]. Imatinib mineralization as a cure for cancer has also been carried out by the EF process, $34.5 \mathrm{mg} / \mathrm{L}$ imatinib is able to be perfectly mineralized for 8 hours using a graphite cathode modified with carbon, and $75 \%$ of the total organic is set aside by this treatment.

\subsection{Fertilizers and Pesticides}

Water pollution by pesticides is often found in surface water and some are found in underground water, the majority of which is used to fulfill daily needs such as water sources for drinking water, cooking and others. The pollution from Karbofuran pesticides has occurred in the waters of Mlonggo Keluran in Jepara Regency with a concentration of $0.005-0.137 \mathrm{ppm}$ caused by agricultural activities in the region [37].

EF technology has been used to exclude insecticidal compounds and organophosphate akarisida, monocrotophos (MCP), from the experiment $65 \% \mathrm{MCP}$ was significantly removed from less than 5 minutes of processing time with an initial concentration of 300 $\mathrm{mg} / \mathrm{L}$ [38]. The short time of degradation can be attributed to the presence of $\mathrm{OH} \bullet$ which helps the oxidation process to be faster so that contaminant compounds can be set aside with a short contact time [38]. Three types of pesticides namely carbofuran, clortoluron and bentazone are processed simultaneously to prove the level of electro-Fenton processing efficiency, $94 \%$ of total organic can be set aside for 480 minutes of processing time with a current of $300 \mathrm{~mA}$, $\mathrm{Fe}^{3+} 0.1 \mathrm{mM}$, electrolyte $\mathrm{Na}_{2} \mathrm{SO}_{4} 50 \mathrm{mM}$ at pH 3 [40]. Electro-Fenton is also able to degrade and mineralize phenylurea (phenylurea herbicide fluometuron (FLM)) under conditions of $0.1 \mathrm{mM} \mathrm{Fe}{ }^{2+}, \mathrm{pH}=3,500 \mathrm{~mA}$ current with BDD anode with mineralization efficiency up to $>98 \%$ [28].

\subsection{Phenol}

Among various types of waste, phenolic compounds are toxic to the flora and fauna that live in water bodies [25]. Phenolic compounds are released in water bodies by wastewater from industries, such as the pharmaceutical industry, oil refineries, coke industries, pulp and paper industries, and food processing industries and various chemical factories [5].

A total of $250 \mathrm{mg} / \mathrm{L}$ phenol compounds in the solution were processed by electro-Fenton with only 5 minutes, the total organic allowance reached $52.2 \%$ but after adding the allowable activated carbon to $75 \%$, the electrodes used were iron electrodes with optimal stoichiometry $\mathrm{pH} 5,2 ; \mathrm{H}_{2} \mathrm{O}_{2}=37.2 \mathrm{mM}$, conductivity $125 \mathrm{~S} / \mathrm{cm}$, stirring speed $100 \mathrm{rpm}$, electrolyte $\mathrm{NaCl}$, current $0.8 \mathrm{~mA} / \mathrm{cm}^{2}$, distance between electrodes $4 \mathrm{~cm}$ [12]. Stainless steel and nickel are used as electrodes to set aside phenol compounds with electro-Fenton with degradation results of $95.2 \%$ using stainless steel for 90 minutes and $72 \%$ using nickel anodes for 120 minutes, currently used is $900 \mathrm{~mA}$, addition of $\mathrm{Fe}^{2+}$ as much as 5 $\mathrm{mg} / \mathrm{L}$ [40].

\subsection{Other}

Types of waste or other contaminants that have been reported set aside by electro-Fenton include industrial waste with processing conditions using iron plate electrodes which are added $\mathrm{H}_{2} \mathrm{O}_{2}$ from outside with a concentration of $0-16 \mathrm{mM}$, current $0.25-1,5 \mathrm{~mA} / \mathrm{cm}^{2}$, with a $\mathrm{pH}$ of 2.7 , from the experimental results obtained the optimal EF condition is to add $12 \mathrm{mM} \mathrm{H}_{2} \mathrm{O}_{2}, \mathrm{pH} 2.7$, current of $1 \mathrm{~mA} / \mathrm{cm}^{2}$ with a processing time of 80 minutes, obtained the COD allowance was 76.3\% [13]. E. Coli bacteria can be deactivated by the EF process, this study was conducted using a batch reactor, the current used was $0.5 \mathrm{~mA}$ using $\mathrm{Pt}$ anode, stainless steel cathode, and the distance between electrodes was $4 \mathrm{~cm}$ [23]. Electro-Fenton process is also used to remove surfactants using carbon cathodes and cylindrical stem anodes with an electrode distance of $1.6 \mathrm{~cm}, \mathrm{H}_{2} \mathrm{O}_{2}$ resulting from $\mathrm{O}_{2}$ reduction produced from injection from the outside at a rate of $1 \mathrm{~L} /$ minute for 10 minutes before electrolysis begins, and stirring is carried out at a speed of $700 \mathrm{rpm}$, the results of this experiment are surfactant sodium dodecyl benzene sulfonate (LAS) capable of being eliminated in the presence of $\mathrm{OH}$ radicals, with a stress condition of $200 \mathrm{~mA}$, catalyst $\mathrm{Fe}^{2+}$ $0.3 \mathrm{mM}$ and $\mathrm{pH} 3$ during 180 minutes which $50 \mathrm{mg} / \mathrm{L}$ LAS is able to be completely eliminated [21].

\section{Conclusion}

The application of EF on removal pollutants from water and wastewater has been used in the last decade. Various affecting factors such as electrode type, $\mathrm{pH}$, current density, $\mathrm{Fe}^{2+}$ and $\mathrm{H}_{2} \mathrm{O}_{2}$ concentration, $\mathrm{O}_{2}$ flow rate, electrode gap, temperature, and electrolyte were observed and compared and this EF process depends on the suitable affecting factors. Pollutant removal such as 
color, leachate, drugs, fertilizers, and pesticides, phenol, biological pollutants, etc has been processed by EF and this process is promoting technologies for applied in industrial wastewater.

\section{References}

1. F.C. Moreira, R.A.R. Boaventura, E. Brillas, V.J.P. Vilar, Appl. Catal. B Environ. 202, 217 (2017)

2. S.O. Ganiyu, M. Zhou, C.A. Martínez-Huitle, Appl. Catal. B Environ. 235, 103 (2018)

3. N. Oturan, M.A. Oturan, Electro-Fenton Process: Background, New Developments, and Applications, Elsevier Inc. (2018)

4. E. Atmaca, J. Hazard. Mater. 163, 109 (2009)

5. P.V. Nidheesh, R. Gandhimathi, Desalination 299, 1 (2012)

6. M. Panizza, G. Cerisola, Chem. Rev. 109, 6541 (2009)

7. C. Zhang, G. Ren, W. Wang, X. Yu, F. Yu, Q. Zhang, M. Zhou, Sep. Purif. Technol. 208, 76 (2019)

8. A. Baiju, R. Gandhimathi, S.T. Ramesh, P.V. Nidheesh, J. Environ. Manage. 210, 328 (2018)

9. H. Zhang, X. Ran, X. Wu, J. Hazard. Mater. 241242, 259 (2012)

10. M. Malakootian, A. Moridi, Process Saf. Environ. Prot. 111, 138 (2017)

11. K. Cruz-González, O. Torres-Lopez, A.M. GarcíaLeón, E. Brillas, A. Hernández-Ramírez, J.M. Peralta-Hernández, Desalination 286, 63 (2012)

12. I. Khatri, S. Singh, A. Garg, J. Environ. Chem. Eng. 6, 7368 (2018)

13. N. Jaafarzadeh, F. Ghanbari, M. Ahmadi, M. Omidinasab, Chem. Eng. J. 308, 142 (2017)

14. Y. Zhang, Z. Chen, P. Wu, Y. Duan, Y. Zhao, L. Zhou, Y. Lai, F. Wang, Mater. Lett. 239, 196 (2019)

15. C.T. Wang, W.L. Chou, M.H. Chung, Y.M. Kuo, Desalination 253, 129 (2010)

16. A. El-Ghenymy, R.M. Rodríguez, C. Arias, F. Centellas, J.A. Garrido, P.L. Cabot, E. Brillas, J. Electroanal. Chem. 701, 7 (2013)

17. T. Sruthi, R. Gandhimathi, S.T. Ramesh, P.V. Nidheesh, Chemosphere 210, 38 (2018)

18. H. Lei, H. Li, Z. Li, Z. Li, K. Chen, X. Zhang, H. Wang, Process Saf. Environ. Prot. 88, 431 (2010)

19. D. Gümüş, F. Akbal, Process Saf. Environ. Prot. 103, 252 (2016)

20. F. Yu, M. Zhou, X. Yu, Electrochim. Acta 163, $182(2015)$

21. M. Panizza, M. Delucchi, A. Giuliano, G. Cerisola, A. Barbucci, M.P. Carpanese, M. CataldoHernández, Sep. Purif. Technol. 118, 394 (2013)

22. S. Loaiza-Ambuludi, M. Panizza, N. Oturan, A. Özcan, M.A. Oturan, J. Electroanal. Chem. 702, 31 (2013)

23. S. Kourdali, A. Badis, A. Boucherit, K. Boudjema, A. Saiba, J. Environ. Manage. 106 (2018)

24. H. Yang, M. Zhou, W. Yang, G. Ren, L. Ma, Chemosphere 206, 439 (2018)
25. A. Akyol, O.T. Can, E. Demirbas, M. Kobya, Sep. Purif. Technol. 112, 11 (2013)

26. M. Pimentel, N. Oturan, M. Dezotti, M.A. Oturan, Appl. Catal. B Environ. 83, 140 (2008)

27. Y. Xia, H. Shang, Q. Zhang, Y. Zhou, X. Hu, J. Electroanal. Chem. 840, 400 (2019)

28. P.A. Diaw, N. Oturan, M.D. G. Seye, A. Coly, A. Tine, J.J. Aaron, M.A. Oturan, Sep. Purif. Technol. 186, 197 (2017)

29. Y. Hu, Y. Lu, G. Liu, H. Luo, R. Zhang, X. Cai, Chemosphere 202, 191 (2018)

30. W. Zhou, L. Rajic, L. Chen, K. Kou, Y. Ding, X. Meng, Y. Wang, B. Mulaw, J. Gao, Y. Qin, A. N. Alshawabkeh, Electrochim. Acta 296, 317 (2019)

31. F.C. Moreira, S. Garcia-Segura, V.J.P. Vilar, R.A.R. Boaventura, E. Brillas, Appl. Catal. B Environ. 142-143, 877 (2013)

32. E. Pajootan, M. Arami, M. Rahimdokht, Sep. Purif. Technol. 130, 34 (2014)

33. L. Zhou, Z. Hu, C. Zhang, Z. Bi, T. Jin, M. Zhou, Sep. Purif. Technol. 111, 131 (2013)

34. E. Guivarch, S. Trevin, C. Lahitte, M.A. Oturan, Environ. Chem. Lett. 1, 38 (2003)

35. K. Cruz-González, O. Torres-López, A. GarcíaLeón, J.L. Guzmán-Mar, L.H. Reyes, A. Hernández-Ramírez, J.M. Peralta-Hernández, Chem. Eng. J. 160, 199 (2010)

36. M. Panizza, M.A. Oturan, Electrochim. Acta 56, 7084 (2011)

37. D.E. Prasetyo, S.Y. Wulandari, D.H. Ismunarti, J. Oseanografi 4, 451 (2015)

38. H. C. Yatmaz, Y. Uzman, Int. J. Electrochem. Sci. 4, 614 (2009)

39. A.K. Abdessalem, N. Bellakhal, N. Oturan, M. Dachraoui, M.A. Oturan, Desalination 250, 450 (2010)

40. M. Radwan, M. Gar Alalm, H. Eletriby, J. Water Process Eng. 22, 155 (2018) 